\title{
Pola Pembelajaran dan Pengasuhan Pendidikan Anak Usia Dini di PAUD Madura
}

\author{
Netty Dyah Kurniasari \\ Puslit Gender dan Kependudukan LPPM Univ. Trunojoyo Madura
}

\begin{abstract}
Abstrak
Penelitian ini bertujuan untuk mengetahui perbedaan pola (metode) pembelajaran pengasuhan, sarana dan prasarana yang diterapkan di sekolah PAUD di Madura.Selain itu juga untuk mengetahui latar belakang sosial, budaya, pendidikan dan ekonomi orang tua peserta didik. Metode penelitian yang digunakan adalah observasi dan wawancara. Subyek penelitian adalah pos PAUD di Kabupaten Bangkalan. Teknik pemilihan subyek berdasarkan purposive sampling. Teknik keabsahan data adalah triangulasi sumber. Hasil penelitian menunjukkan beberaha hal. Pertama, latar belakang ekonomi berpengaruh thd jenis sekolah yang dipilih orang tua siswa. Kedua, sarana dan prasarana yang dimiliki POS PAUD masih minim.Ketiga,pola pengasuhan yang diterapkan bervariasi , mulai dari tipe otoriter, demokrasi dan permisif.
\end{abstract}

Kata kunci : Pola pengajaran, pola asuh, anak usia dini

\section{PENDAHULUAN}

Pendidikan anak usia dini adalah suatu upaya pembinaan yang ditujukan kepada anak sejak lahir sampai dengan usia enam tahun yang dilakukan melalui pemberian rangsangan pendidikan untuk membantu pertumbuhan dan perkembangan jasmani dan rohani agar anak memiliki kesiapan dalam memasuki pendidikan lebih lanjut (UU No 20 tahun 2003) Tentang Sisdiknas). Pos PAUD diselenggarakan dengan prinsip berbasis masyarakat, melibatkan orang tuam mudah, terjangkau, dan bermutu. Eksistensi Pos PAUD di Desa Gili dan Telang diharapkan menjadi tempat bermain yang menyenangkan dan edukatif pada anak usia dini (golden age) masa emas pertumbuhan anak yang diprioritaskan pada anak semenjak lahir hingga berusia 4 (empat) tahun, sebagaimana amanat ketentuan Pasal 109 Undang-undang Sistem Pendidikan Nasional (selanjutnya disebut UU Sisdiknas) bahwa 'salah satu tujuan pendidikan non formal PAUD adalah mengembangkan potensi kecerdasaran spiritual, intelektual, emosional, estetis, kinestetis, dan sosial peserta didik pada masa emas pertumbuhannya dalam lingkungan bermain yang edukatif dan menyenangkan.

Kemajuan dan prestasi anak sangat tergantung terhadap pola pembelajaran yang 
diterapkan di sekolahnya karena sekolah adalah sebagai tempat belajar kedua setelag keluarga. Beberapa hal yang sangat penting terhadap kualitas belajar siswa antara lain metode pembelajaran, kompetensi guru dan sarana (prasarana) yang ada di sekolah.

Selain pola pembelajaran, pola pengasuhan yang dilakukan oleh orang tua juga memegang peranan penting terhadap tumbuh kembang anak. Dalam pola asuh , ada kecenderungan anak untuk meniru apa yang dilakukan olehorang tuanya.

Pola asuh terdiri dari dua kata yaitu pola dan asuh.Pola adalah sistem, model atau cara kerja. Sedangkan Asuh adalah merawat, mendidik, menjaga, membimbing, melatih dan membantu. Bila digabung menjadi satu maka pola asuh adalah cara atau metode mendidik anak yang dipilih oleh pendidik (dalam hal ini bisa orangtua kandung atau wali).Ahli lain mengatakan pola asuh adalah suatu sikap yang dipilih orang tua dalam berhubungan dengan anaknya yang meliputi cara memberikan hadiah, hukuman, cara orang tua menunjukkan otoritas dan cara orang tua memberikan perhatian. (Agustiawati, 2014)

Pola asuh bisa dibagi menjadi 3 (Alfiana, Ester,2013)

1. Pola Asuh Otoriter.

Dalam arti kata, otoriter itu sendiri berarti sewenang-wenang. Pola asuh otoriter ini bercirikan keras, kaku, bersifat paksaan. Orang tua dalam hal ini akan membuat berbagai aturan yang kaku, saklek, walaupun aturan tersebut tidak disukai anak (tidak mau tahu perasaan anak). Ketika anak melanggar peraturan yang dibuat (tidak mematuhinya, maka orang tua tidak segan untuk menghukum baik secaramental atau fisik). Pola otoriter ini punya kelebihan dan kekurangan. Kelebihannya yaitu anak menjadi patuh, sopan rajin, namunkekeuranngnya anak menjadi inder, kurang percaya diri dan kurang bebas. (alfiana, Ester 2013)

2. Pola Asuh Demokratis

Pola asuh ini menempatkan anak dan memberikan kesempatan anak untuk menyampaikan gagasan, pendapat atau keinginannya. Anak bisa terlibat dalam pengambilan keputusan dalam keluarga, komunikasi bersifat terbuka. aturan yang dibuat berdasarkan kesepakatan antara anak dan orang tua. Menurut Ahmadi dalam Alfiana (2013), ciri-ciri pola asuh pola demokratis ada beberapa hal:

a. Memberikan pengarahan tentang perbuatan yang perlu dipertahankan, yang baik dan perbuatan yang tidak baik agar ditinggalkan.

b. Menentukan disiplin dan aturan dengan mempertimbangkan alasan-alasan yang dpat diterima, dipahami dan dimegerti oleh anak.

c. Menciptakan suasana k.omuniatif antar sesama keluarga

d. Menciptakan keharmonisan dalam keluarga

e. Memberikan bimbingan dengan penuh pengertian 
3. Pola Asuh Permisif

Menurut Godam dalam Alfiana (2013), pola asuh permisif adakah pola asuh yang cuek thd anak. Pola asuh ini cenderung membebaskan anak tanpa natas, lemah dalam keteraturan hidup, tidak mengendalikan anak, tidak memiliki standart bagi perilaku anak, dan tidak memberikan hukuman apabila anak melakukan kesalahan.Pola ini terjadi karena orang tua terlalu sibuk dengan pekerjaan dan urusan.Anak hanya diberi harta, materi saja, terserah anak itu mau berkembang dan tumbuh menjadi apa. Mereka memberikan sedikit perhatian dalam membina kemandirian dan kepercayaan diri anak (Basembun dalam Alfiana, 2013)

Pola permisif merupakan jenis pola asuh yang memberikan kebebasan anak untuk mengekspesikan perasaan dan impuls mereka namun memberikan sedikit tuntutan. Orang tua jarang melakukan kontrol yang kuat terhadap perilaku anak mereka. Mereka juga tidak memantau kegiatan anakanak mereka. Orang tua juga jarang mendisiplinkan anak-anak mereka serta antaraorang tua dan anak kurang adanya komunikasi.

Berdasarkan latar belakang di atas,maka penelitian ini bertujuan untuk menganalisa bagaimana pola pembelajaran dan pola pengasuhan yang dilakukan oleh sekolah dan orang tua di Kecamatan Kamal Madura. Metode yang dipilih yaitu wawancara dan observasi langsung. Pemilihan informan dilakukan dengan cara purposive sampling. Subyek penelitian adalah TK dan PAUD di Kec Kamal, guru PAUD serta orang tua wali murid.

\section{HASIL DAN PEMBAHASAN}

Hasil penelitian menunjukkan beberaha hal. Pertama, desa Gili Timur dan Telang merupakan desa yang terletak di Kecamatan Kamal. Desa ini termasuk desa yang tergolong miskin dibandingkan desa lain. Rata-rata pendidikan warga di desa ini adalah SMA dan SMP. Penduduk yang berada di desa ini merupakan campuran antara pendatang dari Surabaya dan penduduk asli Madura (selanjutnya disebut penduduk kampong). Penduduk pendatang dari Jawa (minoritas) memiliki tingkat pendapatan yang lebih tinggi. Sedangkan penduduk kampung rata-rata berpendidikan SMA Kondisi ini menimbulkan gap (perbedaan) besar khususnya akses pendidikan anak, termasuk akses untuk mengiktui sekolah di Pos PAUD. Penduduk pendatang lebih memilih menyekolahkan anaknya tidak di PAUD Desa Gili tapi ke desa lain yang dianggap lebih modern baik dari segi metode pembelajarannya, sarana dan prasarana dan kualitas sumber daya manusia. Sementara itu, penduduk kampung yang mempunyai penghasilan minim lebih memilih menyekolahkan anaknya di PAUD PGRI 3 yang berada di desa Gili tersebut (Observasi dan wawancara, 2016). Alasan orang tua wali menyekolahkan anaknya ke 
sekolah mayoritas karena lokasi sekolah dekat dengan rumah, bukan karena pertimbangan kualitas dan kompetensi guru (sekolah).

Ketika ditanya apakah berkeinginan untuk menyekolahkan anaknya ke jenjang lebih tinggi, mayoritas menjawab berkeinginan. Rata-rata orang tua di $\mathrm{Kec}$ Kamal menyekolahkan anaknya di PAUD setempat, namun ada juga yang tidak menyekolahkan anaknya ke PAUd. Alasan orang tua tidak menyekolahkan di PAUD karena beberapa hal antara lain orang tua tidak memiliki uang, orang tua tidak memiliki waktu untuk mengantar anak sekolah dan jarak rumah dengan sekolah jauh.

Kedua, Pos PAUD yang saat ini dikelola oleh para Kader di lingkungan Desa Gili dan Telang memiliki kurang lebih 100 (seratus) anak dengan jumlah Bunda PAUD sebagai pendidik sebanyak 9 (Sembilan). Di desa ini pendudukanya terdiri dari penduduk pendatang (minoritas, berasal dari JAwa) dan pendudukan kampung Madura. Kondisi kedua warga ini sangat jauh berbeda. Warga pendatang memiliki tingkat pendapatan dan pendidikan yang lebih tinggi (sarjana). Sedangkan penduduk kampung (Madura, matoritas) hanya mengenyam pendidikan SMP (30\%) dan SMA (70\%). Perbadaan ini membawa implikadi pada kecenderungan menyekolah anaknya. anak didik. Dengan jumlah tenaga pengajar 3 tenaga pengajar termasuk kepala sekolah (Ibu Eni). Keberedaan PAUD PGRI 3 ini sangat memprihatinkan baik dari fasilitas, metode pengajaran maupun sumber daya manusianya. Pos PAUD ini tidak memperoleh anggaran dari pemerintah kota Bangkalan. Hingga saat ini tempat Pos PAUD KB PGRI 3 masih mengontrak dengan besar 1 juta per tahun. Pembayaran itu diambil dari infaq wali murid sebesar Rp. 20.000, - yang setiap bulannya. Mengingat kondisi perekonomian orang tua anak-anak berasal dari golongan ekonomi menengah ke bawah dengan mata pencaharian sebagai petani.(Observasi dan wawancara, 2016)

Ketiga, kedua POS PAUD terdapat keterbatasan dalam kemampuan proses pembelajaran. Hal ini dikarenakan pengelola/budan PAUD berasal dari ibu rumah tangga dan kader PKK.Kedua POS PAUD mempunyai masakah yang sama khususnya dari sisi penguasaan metode pembelajaran yang kurang menyenangkan bagi anak usia ini. yaitu proses belajar mengajar yang bersifat monoton, tidak (kurang menyenangkan), Kompetensi dan kemampuan tenaga pengajar dalam memahami kurikulum PAUD dan bahan referensi masih terbatas, mengingat usia tenaga pengajar 50 tahun ke atas. Selain itu kemampuan memahami berkembangnya ilmu pengetahuan dan teknologi sangat terbatas, karena jenjang pendidikan tenaga pengajar rata-rata SMA. Proses belajar mengajar yang digunakan terkesan apa adanya. Hal ini bisa dilihat dari tidak adanya modul pembelajaran sehingga menghambat proses belajar mengajar. Metode pembelajaran yang digunakan tidak (kurang) memperhatikan kebutuhan, 
perkembangan dan kondisi anak. (Observasi dan wawancara, 2016)

Hal tersebut diperparah dengan tidak memadainya sarana dan prasarana pembelajaran, mulai dari tempat yang masih menyewa. Selain lahannya masih bersatatus kontrak (menyewa), bangunannya pun masih berdinding bambu dengan atap asbes, berubin plesteran (semen dan pasir yang dihaluskan). Keramik hanya di depan pintu kelas jika dihitung hanya beberapa buah keramik putih yang dijajar depan pintu. Atapnya pun dari genting yang sudah berlumut.Selain dari segi bangunan sarana pembelajaran yaitu bangku dan meja untuk proses belajar terbuat dari plastik yang kualitasnya rendah, saat ini kondisi bangku tersebut sudah pudar warnanya, menandakan bahwa bangku-bangku itu sudah tua. Hal ini membawa pengaruh terhadap kenyamanan dan proses belajar mengajar serta bermain anak. (Observasi, 2016)

Untuk memudahkan menganalisi penulis membagi menjadi dua kategori,yaitu orang tua yang tingkat pendidikannya sarjana dan yang dibawah sarjana (SMA, SMP dan SD)

Pola pembelajaran yang dilakukan oleh orang tua yang berpendidikan di bawah atau di atas sarjana rata-rata bertipe demokrasi.

Hal ini terlihat dari jawaban informan yang mengatakan bahwa orang tua memberikan kesempatan pada anak untuk membicarakan tentang apa yang diinginkan. Mereka juga merundingkan segala hal yang terjadi kepada anak dan keluarga. Dari 6 informan orang tua, 4 diantaranya mengatakan bahwa mereka menetapkan pola pengasuhan yang demokrasi, namun ada beberapa hal yang otoriter. Adapun beberapa hal yang otoriter tersebut antara lain: Pertama, anak harus selalu patuh terhadapn peraturan yang dibuat orang tua meskipun anak tidak menyukainya . Kedua, orang tua tidak suka mendengar anak membantah perkataan yang ia bicarakan. Semua keputusan berada di tangan orang tua; dan memarahi anak bahkan memukul adalah hal yang wajar dilakukan orang tua. Dalam hal belajar, mereka mewajibkan dan mengharuskan Mengharuskan anak untuk selalu belajar setiap hari meski anak tidak menginginkannya. Jika anak melakukan kesalahan, orang tuaberhak memarahinya bahkan memukul. (Wawancara kepada orang tua wali murid bakti TK BAKTI TELANG, 2016).

Dua informan lain yang pendidikanya di bawah sarjana, memiliki pola pengasuhan yang dominan demokrasi cenderung ke pola permisif.

Beberapa hal pola demokrasi yang dilakukan oleh orang tua antara lain memberikan, mendiskusikan segala hal yang terjadi dalam keluarga. Anak diberi kesempatan untuk mengutarakan apa yang ia inginkan.Selain itu orang tua juga menjelaskan pada anak ke tempat yang inginkan, perbuatan baik dan buruk agar anak bisa menentukan mana yang akan ia pilih. Orang tua dalam tipe demokratis ini juga selalu memberikan jadwal harian 
untuk anak belajar, mereka mengingatkan anak setiap waktu untuk belajar dan selalu bertanya tentang apa yang anak lakukan di sekolah. (Wawancara dengan orang tua wali murid TK BAKTI Telang 2016)

Adapun pola permisif yang dilakukan oleh orang tua berpendidikan di bawah sarjana ini ada beberapa hal antara lain:Mereka meperbolehkan anak untuk bergaul dengan siapapun, asumsinya sebagai orang tua tidak perlu membatasi pergaulan anak. Selain itu orang tua tipe permisif ini selalu memberikan apa yang diinginkan anak, selalu menuruti kemauan anakmeski orang tua tidak menyukainya. Hal tersebut merupakan manifestasi dari cara mereka menunjukkan kasih sayang. Mereka(orang tua) beranggapan bahwa alasan mereka melakukan itu adalah anak sebenarnya mengerti apa yang ia lakukan, sehingga orang tua tidak perlu atau melarang anak untuk melakukan hal yang ia inginkan. Dengan sendirinya anak akan memahami mana yang baik dan yang buruk tanpa harus diberaitahu orang tua. (Wawancara dengan orang tua wali murid, Salma, 2016)

\section{Kesimpulan dan saran}

Dari hasil penelitian didapat kesimpulan bahwa pola pembelajaran yang dilakukan oleh orang tua yang berpendidikan di bawah atau di atas sarjana rata-rata bertipe demokrasi. Sedangkan ada juga yang memiliki pola pengasuhan yang dominan demokrasi cenderung ke pola permisif dan dilakukan oleh orang tua yang pendidikannya di bawah sarjana.

Alasan orang tua wali desa Gili Timur dan Telang di Kecamatan Kamal menyekolahkan anaknya ke sekolah mayoritas karena lokasi sekolah dekat dengan rumah, bukan karena pertimbangan kualitas dan kompetensi guru (sekolah). Hal ini disebabkan karena faktor pendidikan warga yang rata-rata adalah SMA dan SMP. 


\section{Daftar Pustaka}

Agustiawati Isni , 2014, Pengaruh Pola Asuh terhadap Prestasi Belajar Siswa pada MataPelajaran Akuntansi kelas XI di SMA Negeri 26 Bandung.Universitas Pendidikan Indonesia.Repository.upi.edu

Alfiana, Ester N, 2013, Pola Asuh Orang Tua terhadap Anak dalam Keluarga Pada Bidang Pendidikan di Dusun Pandaan Desa Pandanan Kecamatan Wonosari Klaten. Universitas Negeri Yogyakarta

Wawancara dengan orang tua walimurid dan guru PGRI Banyuajuh, Juli 2016 